Volume 13, Nomor 2, November 2021, pp 300-315 Copyright (C) 2017 Jurnal Akuntansi, Program Studi Akuntansi, Fakultas Bisnis, Universitas Kristen Maranatha. ISSN 2085-8698 | e-ISSN 2598-4977. http://journal.maranatha.edu

\title{
Independensi, Pengalaman Kerja Auditor, dan Kualitas Audit Dengan Skeptisisme Profesional Sebagai Variabel Moderasi
}

\author{
Nieke Yunianti ${ }^{1}$ \\ Program Studi Akuntansi - Fakultas Bisnis - Univ. Kristen Maranatha \\ (Jl. Prof. drg. Surya Sumantri, M.P.H. No.65, Bandung, Jawa Barat) \\ Niekeyunianti@gmail.com \\ Yenni Carolina ${ }^{2}$ \\ Program Studi Akuntansi - Fakultas Bisnis - Univ. Kristen Maranatha \\ (Jl. Prof. drg. Surya Sumantri, M.P.H. No.65, Bandung, Jawa Barat) \\ yenzcarolina@gmail.com \\ Vincent Tanu Winata ${ }^{3}$ \\ Program Studi Akuntansi - Fakultas Bisnis - Univ. Kristen Maranatha \\ (Jl. Prof. drg. Surya Sumantri, M.P.H. No.65, Bandung, Jawa Barat) \\ vtanuwinata@gmail.com
}

\begin{abstract}
The motivation of this study is to examine and provide evidence regarding the interaction of the independent variable (X1) and auditor's work experience (X2) with the audit quality variable $(Y)$ and the interaction of the professional skepticism variable $(Z)$ as a moderator variable in strengthening the interaction of X1 and X2 with variables $Y$. The research is focused on active Public Accountants (partner auditors) who are licensed and registered with IAPI. The results of distributing questionnaires to Public Accountants obtained 309 questionnaire sample data. The Slovin technique was used in the data collection technique, while the data analysis used the SEM PLS (Structural Equation Modeling-Partial Least Square) method. This study provides evidence that 1) auditor independence has a positive effect on audit quality, 2) auditor's work experience has a positive effect on audit quality, 3) auditor's professional skepticism has an effect on strengthening the relationship between auditor independence and audit quality, and 4) auditor's professional skepticism has an effect on strengthen the relationship between auditor work experience and audit quality.
\end{abstract}

Keywords: Audit Quality, Independence, Work Experience, and Professional Skepticism

\begin{abstract}
Abstrak
Motivasi penelitian ini adalah untuk menelaah serta memberikan bukti mengenai interaksi variabel independensi (X1) dan pengalaman kerja auditor (X2) dengan variabel kualitas audit (Y) serta interaksi variabel skeptisisme profesional (Z) sebagai variabel moderator dalam memperkuat interaksi variabel X1 dan X2 dengan variabel Y. Penelitian difokuskan kepada Akuntan Publik (partner auditor) aktif yang sudah memiliki ijin dan terdaftar di IAPI. Hasil penyebaran kuesioner kepada Akuntan Publik diperoleh 309 data sampel
\end{abstract}


kuesioner. Teknik Slovin digunakan dalam teknik pengumpulan datanya, sedangkan analisis datanya menggunakan metode SEM-PLS (Structural Equation Modeling-Partial Least Square). Penelitian ini memberikan bukti bahwa 1) independensi auditor berpengaruh positif terhadap kualitas audit, 2) pengalaman kerja auditor berpengaruh positif terhadap kualitas audit, 3) skeptisisme profesional auditor berpengaruh dalam memperkuat hubungan antara independensi auditor dengan kualitas audit, dan 4) skeptisisme profesional auditor berpengaruh dalam memperkuat hubungan antara pengalaman kerja auditor dengan kualitas audit.

\section{Kata Kunci: Kualitas Audit, Independensi, Pengalaman Kerja, dan Skeptisisme Profesional}

\section{Pendahuluan}

Kualitas audit memiliki peranan yang penting dalam meningkatkan kepercayaan, menjaga iklim investasi yang sehat, dan transparansi di setiap negara. Audit yang berkualitas mencerminkan kemampuan auditor untuk melindungi pihak-pihak yang menggunakan laporan keuangan dengan cara mengidentifikasi dan mengungkapkan salah saji material dan informasi asimetri antara pengguna laporan keuangan dengan manajemen. Namun, banyaknya kasus pelanggaran laporan keuangan yang terjadi dan ketidakmampuan auditor untuk mengungkapkannya membuat masyarakat meragukan kualitas audit dari auditor.

Di Indonesia masih ditemukan berbagai permasalahan yang berkaitan dengan kualitas audit, seperti KAP EY (2019) tidak dapat mengungkapkan transaksi perjanjian pengikatan jual beli dengan Hanson Internasional mengenai tanah kavling yang siap bangun dan adanya overstated atas metode pengakuan pendapatan akrual penuh yang digunakan. Partner auditor yang bertanggung jawab (Sherly Jokom) diberikan sanksi larangan berpraktik selama 1 tahun. Kemudian sebelumnya di tahun 2018, KAP Deloitte Indonesia gagal mendeteksi kecurangan yang dilakukan PT. Sunprima Nusantara Pembiayaan dan KAP justru mencantumkan opini wajar tanpa pengecualian. Marlinna dan Merliyana Syamsul selaku Akuntan Publik yang bertanggung jawab diberikan sanksi pembatasan jasa audit selama 12 bulan. Sementara itu, kasus yang terjadi pada tahun 2019, melibatkan direksi BUMN PT. Garuda Indoensia, KAP anggota BDO Internasional Limited, KAP Tanubrata, Sutanto, Fahmi, Bambang, dan Rekan. Pihak akuntan publik gagal menganalisis dan menampilkan nilai transaksi pendapatan dan piutang dengan PT. Mahata, terdapat bukti yang tidak sesuai atas transaksi yang terjadi, dan KAP tidak melaporkan fakta kerjadian setelah tanggal laporan keuangan. Auditor Kasner Sirumapea yang bertanggung jawab diberikan sanksi pencabutan izin praktik selama 1 tahun.

Maraknya berbagai kasus yang menimpa Kantor Akuntan Publik Big 4 maupun KAP Non-Big 4 di atas, menunjukkan kualitas audit di Indonesia masih belum memenuhi standar kualitas yang diharapkan dan berbagai pelanggaran yang dilakukan dalam mengaudit laporan keuangan mengakibatkan timbulnya keraguan integritas akuntan publik oleh pengguna jasa audit. Besarnya tanggung jawab akuntan publik pada pengguna laporan audit mengharuskan akuntan publik memiliki independensi dalam pelaksanaan audit. Independensi merupakan aspek dasar untuk mendapatkan audit yang berkualitas, sebagai pembuktian kredibilitas laporan keuangan perusahaan, dan independensi dapat meningkatkan kemampuan auditor untuk menjaga integritas dan bertindak objektif yang tidak memihak pihak manapun. Oleh sebab itu, peneliti menggunakan independensi sebagai faktor 
yang berpengaruh terhadap kualitas audit karena independensi merupakan jantung dari profesi akuntan publik. Seorang auditor harus memiliki keahlian dan profesional di bidang audit dan akuntansi laporan keuangan yang dapat dicapai melalui pembelajaran pendidikan formal dan dilanjutkan dengan praktik kerja di Kantor Akuntan Publik. Lama waktu dan jumlah pekerjaan yang dikerjakan auditor akan sangat berpengaruh dalam menambah pengalaman kerja auditor sehingga dapat meningkatkan pengalaman kerja dan profesionalisme auditor dalam mengaudit laporan, serta memberikan ketepatan opini yang akan diberikan pada suatu laporan sehingga laporan auditor independennya berkualitas.

Selain independensi dan pengalaman kerja, skeptisme profesional pula dijadikan syarat utama yang harus dimiliki oleh seorang auditor. Skeptisisme profesional meliputi pemikiran yang selalu bertanya dan tidak begitu saja percaya atas informasi dari manajemen. Sikap tersebut dapat membantu auditor dalam penyelesaian tugas audit dan mengurangi kesalahan material yang terjadi. Auditor yang memiliki sikap skeptisme profesional yang rendah dapat menjadi penyebab rendahnya kualitas audit yang dihasilkan dan menimbulkan kecurangan, baik yang telah terjadi maupun yang masih berpotensi menjadi tidak terdeteksi. Sikap tesebut dapat dilatih oleh auditor selama melaksanakan tugas audit, sehingga semakin banyak auditor menerima penugasan audit maka akan semakin terlatih. Pentingnya skeptisme profesional yang harus dimiliki auditor untuk melaksanakan audit, membuat sikap tersebut akan dijadikan sebagai variabel moderasi dalam penelitian ini. Seorang auditor yang memiliki independensi yang tinggi, pengalaman kerja yang mumpuni, dan sikap skeptisisme profesional diharapkan dapat melakukan pemeriksaan audit yang berkualitas sehingga menghasilkan laporan auditan yang andal dan reliabel.
Berdasarkan permasalahan yang telah dipaparkan, maka peneliti tertarik untuk membuktikan secara empiris hubungan dari setiap variabel yang ada. Peneliti menggunakan variabel skeptisme profesional sebagai variabel moderasi karena masih sedikitnya penelitian yang menggunakan variabel tersebut sebagai variabel moderasi. Berbeda dengan penelitian sebelumnya, fokus penelitian ini adalah pada akuntan publik aktif yang terdaftar dan memiliki izin di IAPI Indonesia. Adapun rumusan masalah pada penelitian ini adalah (1) Seberapa besar pengaruh antara independensi auditor terhadap kualitas audit (2) Seberapa besar pengaruh antara pengalaman kerja auditor terhadap kualitas audit (3) Seberapa besar pengaruh skeptisme profesional auditor memoderasi hubungan antara independensi auditor terhadap kualitas audit (4) Seberapa besar pengaruh skeptisme profesional auditor memoderasi hubungan antara pengalaman kerja auditor terhadap kualitas audit.

\section{Kerangka Teoritis dan Hipotesis}

\section{Kualitas Audit}

Kualitas audit merupakan peluang auditor untuk menemukan dan meminimalkan risiko salah saji material dalam pemeriksaan sistem akuntansi ataupun laporan auditor independen. Kualitas audit merupakan hasil pekerjaan auditor yang dibuktikan dengan laporan audit yang andal sesuai dengan prosedur dan standar yang ditentukan. Dalam mencapai kualitas audit yang diharapkan, auditor harus sinkorn dengan SPAP, yang di dalamnya meliputi prinsip dan tanggung jawab auditor, penilaian risiko dan respon terhadap risiko yang dinilai, prosedur mendapatkan bukti audit, penggunaan hasil pekerjaan pihak lain, kesimpulan auditor dan pelaporan, serta area khusus.

Dimensi kualitas audit yang dijadikan parameter dalam penelitian ini sesuai dengan penelitian Wooten (2003), yakni: 
a. Deteksi salah saji, yang dimana auditor harus mempunyai sikap serta pikiran selalu bertanya dan menganalisis bukti yang diberikan oleh perusahaan.

b. Ketaatasaan pada SPAP, tolok ukur yang digunakan sebagai parameter kualitas yang wajib ditaati oleh auditor dalam pelaksanaan penugasan perikatan audit.

c. Taat pada SOP, tentang apa yang harus dilakukan, kapan, dimana, oleh siapa, bagaimana cara melakukan dan apa saja yang diperlukan dalam melaksanakan pekerjaan audit.

Peneliti menggunakan dimensi ini karena menurut De Angelo (1981) kualitas audit merupakan probabilitas pelanggaran dalam sistem akuntansi yang akan ditemukan oleh auditor, sehingga apabila auditor dapat menemukan salah saji dengan melakukan pelaksanaan pemeriksaan dan pengumpulan bukti yang berpedoman pada SPAP dan SOP yang berlaku, maka diharapkan dapat menghasilkan laporan audit yang berkualitas.

\section{Independensi}

Independensi merupakan perilaku objektif yang terbebas dari tekanan, tidak dikendalikan, dan tidak bergantung pada semua pihak dalam mengambil keputusan tentang pekerjaan audit dan pelaporan keuangan. Independensi auditor diakui sebagai mekanisme penting dalam mengurangi asimetri informasi, karena independensi auditor akan memastikan bahwa auditor menyajikan pandangan objektif yang andal dan jujur tentang laporan keuangan yang disiapkan oleh perusahaan. Terdapat 5 hal yang dapat mengganggu independensi auditor, yakni Self-interest threats; Self-review threat; Advocary threats; Familiarity threats; dan Intimidation threats.

Dimensi independensi yang dijadikan parameter dalam penelitian ini sesuai dengan penelitian Mautz dan Sharaf (1961), yakni:
a. Independensi Penyusunan Program

(Programming Independence), yakni memberi ruang untuk auditor menentukan strategi yang dianggap tepat saat melakukan audit melalui pengembangan sendiri program audit dan pekerjaan apa yang akan dilakukan selama sesuai dengan batas keterikatan audit.

b. Independensi Investigasi (Investigative Independence), yakni melindungi kemampuan auditor untuk mengimplementasikan strategi pengumpulan bukti audit yang telah dibuat dengan cara apapun yang dianggap perlu.

c. Independensi Pelaporan (Reporting Independence), yakni auditor bebas dari tekanan atau pengaruh pihak manapun dalam mengemukakan opini.

\section{Pengalaman Kerja}

Pengalaman kerja adalah pengalaman yang diperoleh auditor selama melakukan proses audit laporan keuangan baik dari segi lamanya waktu maupun banyaknya penugasan yang pernah ditangani. Semakin berpengalaman auditor, maka semakin besar peluang menemukan berbagai temuan audit dan dapat mempengaruhi kualitas audit.

Dimensi pengalaman kerja yang dijadikan parameter dalam penelitian ini sesuai dengan penelitian Foster (2001), yakni:

a. Lama waktu/masa bekerja, yakni periode yang sudah dilalui sehingga dapat menguasai suatu pekerjaan dan sudah melakukannya dengan baik.

b. Tingkat pengetahuan dan keterampilan, yakni pengetahuan mengenai suatu pekerjaan, kompetensi untuk memahami dan pengaplikasian informasi sehubungan dengan pekerjaan.

c. Penguasaan terhadap pekerjaan dan peralatan, yakni kecakapan dalam menggunakan teknik peralatan serta kemahiran dalam pekerjaan. 


\section{Skeptisme Profesional Auditor}

Skeptisisme profesional adalah perilaku yang meliputi pikiran yang selalu bertanya, cermat pada suatu keadaan yang menunjukkan salah saji material yang diakibatkan oleh kekeliruan maupun kesengajaan serta pertimbangan fundamental dari bukti audit.

Dimensi skeptisme profesional auditor yang dijadikan parameter dalam penelitian ini sesuai dengan penelitian Hurtt (2010), Shahibah et al (2020), Luthfiana (2018), dan Nandari dan Latrini (2015), yakni:

a. Questioning Mind (indikator: "kecurigaan terhadap pernyataan atau bukti yang didapatkan" dan "mengajukan banyak pertanyaan untuk berbagai hal yang meragukan").

b. Suspension of Judgment (indikator: "tidak terburu-buru membuat keputusan selama proses audit" dan "tidak membuat keputusan jika informasi dan bukti suatu asersi belum lengkap dan memadai").

c. Seacrhing for knowledge (indikator: "berusaha mempelajari dan menemukan informasi baru" dan "bertanya dan berdiskusi dengan rekan apabila terdapat hal baru yang meragukan").

d. Interpersonal understanding (indikator: "berusaha memahami perilaku pemberi informasi dan bukti audit" dan "kewaspadaan bukti audit yang diberikan oleh klien").

e. Self confidence (indikator: "percaya pada kemampuan diri sendiri untuk mengambil keputusan berdasarkan bukti yang memadai" dan "kemampuan dalam mempertahankan opini yang sudah ditetapkan oleh auditor").

f. Self determintation (indikator: "tidak mudah dipengaruhi oleh orang lain dalam pembuatan keputusan" dan "kemampuan auditor untuk menjelaskan opini atau pendapat yang dihasilkan auditor").

\section{Pengaruh Independensi Auditor Terhadap Kualitas Audit}

Landasan atau fondasi bagi profesi auditor adalah independensi (Grampling dan Karapanos, 2008). Independensi merupakan sikap mental ketidakberpihakan pada pihak manapun sehubungan dengan pemeriksaan laporan keuangan yang dilakukan auditor. Sikap dan sifat ini penting bagi profesi akuntan publik karena besarnya rasa percaya pengguna laporan pada auditor (Prasanti et al., 2019).

Shahibah et al (2020) melakukan penelitian di KAP Big Ten yang terdaftar di IAPI mengenai pengaruh etika dan independensi serta skeptisisme profesional yang dijadikan variabel moderator. Peneliti mengemukakan hasil independensi dan etika auditor berpengaruh langsung dan positif terhadap kualitas audit. Hal ini dapat dikatakan auditor yang bekerja di sepuluh besar KAP telah menerapkan kebijakan mengenai independensi sesuai dengan ketentuan yang telah diatur. Selain itu, skeptisisme profesional memoderasi interaksi independensi dengan kualitas audit tetapi tidak memoderasi interaksi etika audit dengan kualitas audit. Penelitian Santoso et al (2020) di KAP Kota Surabaya perihal hubungan independensi, integritas dan kompetensi auditor terhadap kualitas audit dengan skeptisisme profesional sebagai variabel moderasi menemukan bahwa independensi, integritas, kompetensi auditor dan skeptisisme profesional berpengaruh positif terhadap kualitas audit. Artinya membuktikan bahwa semakin auditor sadar pentingnya independensi, integritas, kompentensi auditor dan skeptisisme profesional seorang auditor dalam melakukan pemeriksaan maka semakin baik kualitas laporan audit yang dihasilkan.

Menurut pemaparan para peneliti yang telah dijabarkan diatas, dapat dikatakan independensi auditor diduga akan meningkatkan kualitas audit. Seorang auditor diharapkan bebas dari intervensi pihak manapun dan dapat bersikap sesuai fakta yang ditemukan di lapangan, serta menyajikan fakta yang ditemukan tersebut 
sebagai laporan audit menurut standar audit yang berlaku. Berdasarkan hal tersebut penulis merumuskan hipotesis sebagai berikut:

H1 : Independensi auditor berpengaruh positif terhadap kualitas audit

\section{Pengaruh Pengalaman Kerja Auditor Terhadap Kualitas Audit}

Pengalaman kerja merupakan suatu parameter lama waktu atau masa kerja yang ditempuh seseorang untuk menguasai pekerjaan dan melaksanakannya dengan baik (Foster, 2001). Pengalaman auditor merupakan proses pembelajaran dan penambahan perilaku potensial saat berkorelasi dengan pekerjaan yang dikerjakan selama periode tertentu. Semakin lama pengalaman seorang auditor maka semakin baik kualitas audit yang dhasilkan, lebih berpengalaman auditor lebih mudah untuk menemukan penyimpangan dan mengetahui penyebabnya (Prasanti et al., 2019). Prasanti, et al (2019) meneliti seluruh KAP di DKI Jakarta menjabarkan bahwa pengalaman kerja auditor berpengaruh positif terhadap kualitas audit dan etika profesional yang digunakan sebagai variabel moderasi terbukti memperkuat hubungan antara pengalaman kerja dengan kualitas audit. Sejalan dengan penelitian tersebut, Sarca dan Rasmini (2019) yang melakukan penelitian di Provinsi Bali menemukan hasil variabel pengalaman kerja berpengaruh positif terhadap kualitas audit, dan hubungan pengalaman kerja dengan kualitas audit dapat diperkuat oleh etika auditor. Begitu pula penelitian Ningrum dan Budiartha (2017) menunjukkan hasil kualitas audit dipengaruhi oleh pengalaman kerja dan bersifat positif dan signifikan. Penelitian yang dilakukan di Bali ini menemukan pula bahwa etika profesional memperkuat pengaruh pengalaman auditor pada kualitas audit. Dengan ini artinya pengalaman kerja dipengaruhi oleh etika profesional, jadi auditor yang memiliki pengalaman tinggi akan meningkatkan kualitas audit jika didukung dengan perilaku etika yang positif atau sebaliknya jika didukung dengan perilaku yang negatif maka kualitas audit hasil pemeriksaan akan menurun (Ningrum dan Budiartha, 2017).

Berdasarkan uraian yang telah dijabarkan diatas oleh para peneliti terdahulu, peneliti menyimpulkan lama waktu auditor bekerja akan menambah kompetensi dan kemampuan dalam mengaudit berbagai jenis laporan keuangan perusahaan klien yang diharapkan melaksanakan audit sesuai standar audit dan menghasilkan laporan berkualitas. Berdasarkan alasan tersebut penulis merumuskan hipotesis sebagai berikut:

H2 : Pengalaman kerja auditor berpengaruh positif terhadap kualitas audit

\section{Pengaruh Skeptisisme Profesional Auditor dalam Memperkuat Hubungan antara Independensi dan Pengalaman Kerja Auditor terhadap Kualitas Audit}

Skeptisisme profesional adalah perilaku yang meliputi pikiran yang selalu bertanya, cermat pada suatu keadaan yang menunjukkan salah saji material yang diakibatkan oleh kekeliruan maupun kesengajaan serta pertimbangan fundamental dari bukti audit. Attamimi dan Riduan (2015) kemudian menjelaskan bahwa sikap skeptisisme profesional dari akuntan publik akan sangat diperlukan karena masyarakatluas akan menjadi penilai laporan keuangan yang telah diaudit. Skeptisisme dapat diasah auditor selama melakukan audit. Skeptisisme profesional dapat melahirkan kompetensi profesional auditor, yang kemudian akan menambah akurasi dalam pemilihan opini, sehingga secara tidak langsung diharapkan akan meningkatkan kualitas laporan audit yang dihasilkan (Tawakal, 2019).

Penelitian Hai, et al (2020) terhadap 513 Kantor Akuntan Publik yang terdaftar di Vietnam menemukan bahwa kualitas audit dipengaruhi oleh skeptisisme profesional. Skeptisisme profesional yang diteliti dilihat dari aspek sifat dan kepribadian auditor, insentif, karakteristik bukti audit, sifat, pengetahuan dan 
pengalaman dan waktu serta beban kerja audit. Shahibah, et al (2020) dalam penelitiannya menggunakan skeptisisme profesional sebagai variabel moderator antara etika auditor dan independensi terhadap kualitas audit. Hasil membuktikan variabel skeptisisme profesional tidak menjadi penghubungan interaksi etika dengan kualitas audit sedangkan untuk independensi menemukan bahwa skeptisisme profesional memoderasi hubungan independensi dengan kualitas audit. Dapat dikatakan semakin independen auditor, maka akan meningkatkan kemampuan untuk mendeteksi kecurangan sehingga audit lebih berkualitas dengan dukungan dari skeptisisme profesional. Penelitian Santoso, et al (2020) di Kota Surabaya tentang pengaruh independensi, integritas dan kompetensi auditor terhadap kualitas audit dengan skeptisisme pofesional sebagai variabel moderasi menemukan bahwa skeptisisme profesional mampu memoderasi hubungan independensi terhadap kualitas audit, dapat dijelaskan bahwa semakin tinggi sikap skeptisisme seorang auditor maka akan semakin kuat sikap independensinya sehingga dapat meningkatkan kualitas audit.

Menurut uraian yang sudah diteliti oleh para peneliti sebelumnya peneliti menyimpulkan bahwa skeptisisme profesional auditor mempunyai pengaruh dalam memperkuat hubungan independensi dan pengalaman kerja terhadap kualitas audit. Perilaku skeptis auditor akan meningkatkan independensi auditor sehingga akan mendeteksi kecurangan dalam laporan keuangan menemukan bukti yang relevan sesuai dengan standar audit, dengan begitu diharapkan akan meningkatkan kualitas laporan keuangan. Berdasarkan alasan tersebut penulis merumuskan hipotesis sebagai berikut:

H3 : Skeptisisme profesional auditor berpengaruh dalam memperkuat hubungan antara independensi auditor terhadap kualitas audit

H4 : Skeptisisme profesional auditor berpengaruh dalam memperkuat hubungan antara pengalaman kerja auditor terhadap kualitas audit

\section{Metode Penelitian}

Objek yang digunakan dalam penelitian ini adalah kualitas audit, independensi, pengalaman kerja, dan skeptisme profesional. Subjeknya yang akan digunakan adalah akuntan publik aktif yang terdaftar di IAPI dan memiliki izin untuk melakukan perikatan audit. Penelitian ini menggunakan metode verifikatif (untuk membuktikan dan memverifikasi seberapa besar pengaruh variabel yang akan digunakan) dan metode deskriptif (metode analisis yang menggambarkan karakteristik populasi atau fenomena yang diteliti serta menafsirkan objek sesuai dengan situasi).

Populasi yang digunakan dalam penelitian ini berjumlah 1.312 Akuntan Publik aktif. (1.363 Akuntan Publik terdaftar dan pemegang izin AP dikurangi 39 Akuntan Publik yang tidak aktif karena cuti dan dikurangi 12 Akuntan Publik yang tidak aktif karena sebab lain). Peneliti menggunakan rumus teknik slovin untuk menghitung sampel yang akan diambil dengan menetapkan tingkat kesalahan sebesar 5\%, sehingga didapati hasil sampel yang akan digunakan adalah 307 Akuntan Publik aktif. Kemudian sampel akan diseleksi dengan menggunakan metode simple random sampling (sampel diseleksi secara random tanpa memperhatikan tingkatan populasi).

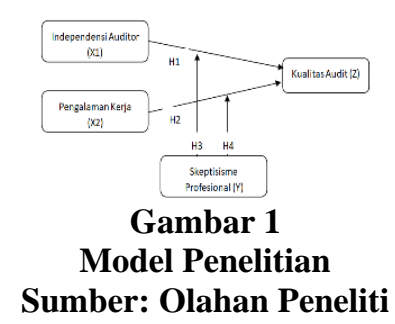

Instrumen penelitian yang digunakan adalah kuesioner/angket. Kuesioner yang akan digunakan merupakan kuesioner pertanyaan 
tertutup agar jawaban yang diperoleh dari responden dapat diolah secara kuantitatif. Skala pengukuran yang digunakan pada setiap pertanyaan adalah skala interval (menyatakan kategori dan peringkat construct yang diukur). Teknik pemberian skor menggunakan skala likert. Metode SEM dengan partial least square digunakan untuk menganalisis dan menguji data, serta metode ini dipilih karena adanya variabel moderating dan jumlah sampel terbatas dalam penelitian ini.

\section{Hasil Penelitian dan Pembahasan}

\section{Karakteristik Responden}

a. Berdasarkan Jabatan

Responden yang menjawab kuesioner, $100 \%$ merupakan partner atau 309 responden merupakan partner auditor.

b. Berdasarkan Lama Bekerja

Responden dengan lama waktu kerja 510 tahun sebanyak $23.62 \%$ atau 73 orang responden, sedangkan responden dengan lama waktu kerja diatas 10 tahun sebanyak $76.38 \%$ atau 236 responden.

c. Berdasarkan Jenis Kelamin

Responden laki-laki sebanyak $65.37 \%$ atau 202 respoden, sedangkan respoden perempuan sebanyak $34.63 \%$ atau 107 responden.

d. Berdasarkan Usia

Responden dengan rentang umur 23-30 tahun sebesar $1.62 \%$ atau 5 orang, lalu rentang umur 31-50 tahun sebesar $54.05 \%$ atau 167 responden, dan umur diatas 50 tahun sebesar $44.34 \%$ atau 137 responden.

e. Berdasarkan Tingkat Pendidikan

Responden dengan tingkat pendidikan Magister (S2) sebanyak $55.66 \%$ atau 172 responden, lalu dengan tingkat pendidikan Sarjana (S1) sebanyak $27.15 \%$ atau 85 responden, dan dengan tingkat pendidikan Doktor (S3) sebanyak $16.83 \%$ atau 52 responden.

\section{Hasil Uji Validitas dan Reliabilitas}

Variabel independensi (terdiri 9 item); variabel pengalaman kerja (terdiri 7 item); variabel skeptisme profesional (terdiri 18 item); dan kualitas audit (terdiri 8 item) menunjukkan nilai koefisien korelasi (r) dari setiap pernyataan lebih besar dari nilai kritis 0.3 , sehingga pernyataan masingmasing variabel dinilai valid dan layak digunakan sebagai alat ukur penelitian. Demikian halnya untuk uji reliabilitas, semua konstruk dinyatakan reliabel karena menunjukkan nilai koefisien kuesioner pada 4 variabel yang digunakan lebih besar dari nilai kritis 0.6, sehingga dinilai reliabel (konsisten).

\section{Analisis Deskriptif}

a. Analisis Deskriptif Independensi Auditor

- Rata-rata respon responden secara keseluruhan didapati hasil 4.45 (dari skala 1-5). Hal ini menjelaskan bahwa mayoritas auditor di Indonesia sudah memiliki perilaku independensi dalam melaksanakan tugasnya.

- Dimensi independensi penyusunan program (PI), diperoleh rata-rata nilai responden sebesar 4.53 (dari skala 1-5). Hal ini menunjukkan bahwa umumnya auditor di Indonesia sudah sangat independen dalam penyusunan program.

- Dimensi independensi dalam investigasi, diperoleh nilai rata-rata sebesar 4.35 (dari skala 1-5). Hal ini menjelaskan bahwa mayoritas auditor di Indonesia sudah independen dalam investigasi.

- Dimensi independensi dalam pelaporan, diperoleh nilai rata-rata sebesar 4.48 (dari skala 1-5). Hasil ini menjelaskan bahwa mayoritas auditor di Indonesia sudah independen dalam pelaporan.

b. Analisis Deskriptif Pengalaman Kerja Auditor

- Nilai rata-rata responden secara keseluruhan didapati hasil 4.26 
(dari skala 1-5). Hal ini menjelaskan bahwa mayoritas auditor di Indonesia sudah memiliki pengalaman kerja yang memadai.

- Dimensi masa kerja, diperoleh nilai rata-rata sebesar 4.23 (dari skala 1-5). Hal ini menunjukkan bahwa pada umumnya auditor sudah memiliki masa kerja yang memadai.

- Dimensi pengetahuan dan keterampilan, diperoleh nilai ratarata sebesar 4.29 (dari skala 1-5). Hal ini menunjukkan bahwa kebanyakan auditor telah memiliki pengetahuan dan keterampilan yang memadai.

- Dimensi penguasaan terhadap peralatan dan pekerjaan, diperoleh nilai rata-rata sebesar 4.26 (dari skala 1-5). Hal ini menunjukkan bahwa mayoritas auditor sudah kompeten dalam penguasaan pekerjaan dan peralatan.

c. Analisis Deskriptif Skeptisme Profesional Auditor

- Nilai rata-rata responden secara keseluruhan didapati hasil 4.43 (dari skala 1-5). Hal ini menjelaskan bahwa mayoritas auditor di Indonesia mempunyai skeptisme profesional yang bagus.

- Dimensi pikiran yang selalu bertanya, diperoleh nilai rata-rata sebesar 4.50 (dari skala 1-5). Hal ini menunjukkan bahwa auditor sering bertanya ketika melakukan tugas audit.

- Dimensi suspensi pada penilaian, diperoleh nilai rata-rata 4.40 (dari skala 1-5). Hal ini menunjukkan bahwa kebanyakan auditor mempertimbangkan dengan matang sebelum membuat keputusan.

- Dimensi mempelajari pengetahuan, diperoleh nilai rata-rata 4.44 (dari skala 1-5). Hal ini menunjukkan bahwa kebanyakan auditor senang mempelajari sesuatu yang baru.

- Dimensi percaya diri, diperoleh nilai rata-rata 4.37 (dari skala 1-5). Hal ini menunjukkan bahwa mayoritas auditor memiliki percaya diri yang tinggi.

- Dimensi keteguhan hati, diperoleh nilai rata-rata 4.38 (dari skala 1-5). Hal ini menunjukkan bahwa mayoritas auditor teguh pada keputusan yang telah dibuat.

d. Analisis Deskriptif Kualitas Audit

- Nilai rata-rata responden secara keseluruhan didapati hasil 4.57 (dari skala 1-5). Hal ini menunjukkan bahwa pada umumnya auditor di Indonesia memiliki hasil audit yang sangat berkualitas.

- Dimensi salah saji, diperoleh nilai rata-rata 4.52 (dari skala 1-5). Hal ini menunjukkan bahwa kebanyakan auditor memiliki kemampuan yang baik dalam mendeteksi salah saji.

- Dimensi kesesuaian dengan SPAP, diperoleh nilai rata-rata 4.58 (dari skala 1-5). Hal ini menunjukkan mayoritas auditor melakukan penugasan sesuai dengan SPAP yang berlaku.

- Dimensi kepatuhan terhadap SOP, diperoleh nilai rata-rata 4.58 (dari skala1-5). Hal ini menunjukkan kebanyakan auditor melakukan penugasan sesuai dengan SOP yang berlaku.

\section{Evaluasi Model Pengukuran}

Model pengukuran merupakan bentuk gambaran hubungan variabel laten dengan variabel manifes. Pada penelitian ini terdapat 19 variabel laten dengan jumlah variabel manifest sebanyak 42. Variabel manifes yang loading faktornya kurang dari 0.4 , harus direduksi dari model pengukuran dan nilai composite reliability antara 0.70 hingga 0.90 dianggap memuaskan. Loading faktor yang didapati pada diagram jalur full 
model penelitian, memperlihatkan loading faktor semua indikator lebih besar dari 0.5, sehingga seluruh indikator valid untuk mengukur variabel latennya.

a. Evaluasi model pengukuran variabel independensi auditor

- Pada dimensi independensi dalam penyusunan program, indikator IND1 (bebas dari campur tangan apapun dan siapapun yang berkenaan dengan penerapan prosedur dan penyusunan program audit) memiliki loading faktor paling besar/paling kuat dalam mencerminkan dimensi ini dan indikator IND3 (independen dari upaya pemaksaan pihak luar untuk melakukan review audit selain yang diatur dalam proses audit) paling lemah dalam mencerminkan dimensi ini. Nilai EVA sebesar 0.694 atau rata-rata $69.4 \%$ informasi yang terdapat pada masing-masing indikator dapat tercermin melalui dimensi ini.

- Pada dimensi independensi dalam investigasi, indikator IND4 (semua buku perusahaan, catatan, pimpinan dan pegawai perusahaan serta sumber informasi lainnya dapat diperiksa auditor sehubungan kepentingan investigasi) memiliki loading faktor paling besar/paling kuat dalam mencerminkan dimensi ini dan indikator IND6 paling lemah dalam mencerminkan dimensi ini. Nilai EVA sebesar 0.637 atau ratarata $63.7 \%$ informasi yang terdapat pada masing-masing indikator dapat tercermin melalui dimensi ini.

- Pada dimensi independensi dalam pelaporan, indikator IND8 (tidak menggunakan bahasa yang ambigu atau tidak jelas dalam laporan maupun pertimbangan audit) memiliki loading faktor paling besar/paling kuat dalam mencerminkan dimensi ini dan indikator IND7 paling lemah dalam mencerminkan dimensi ini. Nilai
EVA sebesar 0.653 atau rata-rata $65.3 \%$ informasi yang terdapat pada masing-masing indikator dapat tercermin melalui dimensi ini.

- Nilai composite reliability didapati hasil sebesar 0.906 lebih besar dari 0.7, sehingga ketiga dimensi mempunyai konsistensi untuk mengukur independensi auditor. Nilai EVA didapati sebesar 0,763 atau rata-rata $76.3 \%$ informasi yang didapat terdapat pada masingmasing dimensi dapat tercermin melalui variabel laten independensi auditor.

- Hasil menunjukkan bahwa independensi dalam penyusunan program merupakan faktor yang lebih penting dalam mencerminkan independensi auditor, disusul kemudian dimensi independensi dalam pelaporan, dan yang terakhir independensi dalam investigasi.

b. Evaluasi model pengukuran variabel pengalaman kerja auditor

- Pada dimensi masa kerja, indikator PA2 (melaksanakan tugas dengan baik) memiliki loading faktor paling besar/paling kuat dalam mencerminkan dimensi ini dan indikator PA1 (pemahaman auditor mengenai tugas dan pekerjaan) paling lemah dalam mencerminkan dimensi ini. Nilai EVA sebesar 0.651 atau rata-rata $65.1 \%$ informasi yang terdapat pada masing-masing indikator dapat tercermin melalui dimensi ini.

- Pada dimensi pengetahuan dan keterampilan, indikator PA4 (kemampuan memahami informasi) memiliki loading faktor paling besar/paling kuat dalam mencerminkan dimensi ini dan indikator PA6 (kemampuan auditor dalam menerapkan informasi) paling lemah dalam mencerminkan dimensi ini. Nilai EVA sebesar 0.739 atau rata-rata $73.9 \%$ informasi yang terdapat pada 
masing-masing indikator dapat tercermin melalui dimensi ini.

- Pada dimensi penugasan terhadap peralatan dan pekerjaan, indikator PA7 (pengetahuan mengenai aspek-aspek teknik audit eksternal) memiliki loading faktor paling besar/paling kuat dalam mencerminkan dimensi ini dan indikator PA6 (penugasan tugas auditor) paling lemah dalam mencerminkan dimensi ini. Nilai EVA sebesar 0.793 atau rata-rata 79.3\% informasi yang terdapat pada masing-masing indikator dapat tercermin melalui dimensi ini.

- Nilai composite reliability didapati hasil sebesar 0.864 lebih besar dari 0.7, sehingga ketiga dimensi mempunyai konsistensi untuk mengukur pengalaman kerja auditor. Nilai EVA didapati sebesar 0,681 atau rata-rata $68.1 \%$ informasi yang didapat terdapat pada masing-masing dimensi dapat tercermin melalui variabel laten pengalaman kerja.

- Hasil yang didapat menjelaskan bahwa masa kerja adalah faktor yang lebih utama dalam mencerminkan pengalaman kerja auditor, disusul kemudian dimensi penugasan terhadap peralatan dan pekerjaan, dan yang terakhir pengetahuan dan keterampilan.

c. Evaluasi model pengukuran variabel skeptisme profesional auditor

- Pada dimensi pikiran yang selalu bertanya, indikator SP1 (mengajukan banyak pertanyaan untuk pembuktian), memiliki loading faktor paling besar/paling kuat dalam mencerminkan dimensi ini dan indikator SP2 (mengajukan banyak pertanyaan untuk hal-hal yang meragukan) paling lemah dalam mencerminkan dimensi ini. Nilai EVA sebesar 0.646 atau ratarata $64.6 \%$ informasi yang terdapat pada masing-masing indikator dapat tercermin melalui dimensi ini.

- Pada dimensi suspensi pada penilaian, indikator SP6 (berdiskusi sebelum membuat keputusan dan pertimbangan audit), memiliki loading faktor paling besar/paling kuat dalam mencerminkan dimensi ini dan indikator SP4 (pengumpulan informasi dan bukti yang valid sebelum membuat keputusan) paling lemah dalam mencerminkan dimensi ini. Nilai EVA sebesar 0.607 atau rata-rata $60.7 \%$ informasi yang terdapat pada masing-masing indikator dapat tercermin melalui dimensi ini.

- Pada dimensi mencari pengetahuan, indikator SP8 (menyenangkan dapat belajar suatu hal baru), memiliki loading faktor paling besar/paling kuat dalam mencerminkan dimensi ini dan indikator SP7 (berusaha mencari dan menemukan informasi baru) paling lemah dalam mencerminkan dimensi ini. Nilai EVA sebesar 0.633 atau rata-rata $63.3 \%$ informasi yang terdapat pada masing-masing indikator dapat tercermin melalui dimensi ini.

- Pada dimensi pemahaman interpersonal, indikator SP11 (berusaha memahami alasan mengapa seseorang berperilaku), memiliki loading faktor paling besar/paling kuat dalam mencerminkan dimensi ini dan indikator SP12 (mencari kebenaran atas informasi yang diberikan klien) paling lemah dalam mencerminkan dimensi ini. Nilai EVA sebesar 0.606 atau rata-rata $60.6 \%$ informasi yang terdapat pada masing-masing indikator dapat tercermin melalui dimensi ini. 
- Pada dimensi percaya diri, indikator SP13 (percaya akan kapasitas dan kemampuan diri sendiri), memiliki loading faktor paling besar/paling kuat dalam mencerminkan dimensi ini dan indikator SP15 (pengumpulan bukti dan informasi yang konsisten) paling lemah dalam mencerminkan dimensi ini. Nilai EVA sebesar 0.584 atau rata-rata $58.4 \%$ informasi yang terdapat pada masing-masing indikator dapat tercermin melalui dimensi ini.

- Pada dimensi penentuan sendiri, indikator SP18 (dapat menjelaskan dengan baik pernyataan atau pendapat), memiliki loading faktor paling besar/paling kuat dalam mencerminkan dimensi ini dan indikator SP16 (tidak mudah dipengaruhi pihak manapun) paling lemah dalam mencerminkan dimensi ini. Nilai EVA sebesar 0.588 atau rata-rata $58.8 \%$ informasi yang terdapat pada masing-masing indikator dapat tercermin melalui dimensi ini.

- Nilai composite reliability didapati hasil sebesar 0.986 lebih besar dari 0.7, sehingga keenam dimensi mempunyai konsistensi untuk menilai skeptisme profesional. Nilai EVA didapati sebesar 0,668 atau rata-rata $66.8 \%$ informasi yang didapat terdapat pada masing-masing dimensi dapat tercermin melalui variabel laten skeptisme profesional auditor.

- Hasil yang didapat menunjukkan bahwa suspensi pada penilaian merupakan faktor yang lebih utama dalam mencerminkan skeptisisme profesional auditor, disusul kemudian dimensi penentuan sendiri, dan yang paling lemah pikiran yang selalu bertanya. d. Evaluasi model pengukuran variabel kualitas audit

- Pada dimensi deteksi salah saji, indikator KA1 memiliki loading faktor lebih besar/lebih kuat dibandingkan indikator lainnya pada dimensi ini. Nilai AVE sebesar 0.784, menunjukkan bahwa secara rata-rata $78.4 \%$ informasi yang terdapat pada masing-masing indikator tercermin melalui dimensi deteksi salah saji.

- Pada dimensi kesesuaian dengan SPAP, indikator KA4 (memahami penugasan berdasarkan SPAP yang berlaku) memiliki loading faktor paling besar/paling kuat dalam mencerminkan dimensi ini dan KA5 (penerapan SPAP dalam penugasan audit) paling lemah untuk mencerminkan dimensi ini. Nilai EVA sebesar 0.673 , menunjukkan rata-rata $67.3 \%$ informasi yang terdapat pada masing-masing indikator dapat tercermin melalui dimensi ini.

- Pada dimensi kepatuhan terhadap SOP, indikator KA8 (manajer mensupervisi penerapan SOP dalam pelaksanaan tugas audit) memiliki loading faktor paling besar/paling kuat dalam mencerminkan dimensi ini dan KA6 (SOP membuat lebih terarah dalam penugasan audit) paling lemah untuk mencerminkan dimensi ini. Nilai EVA sebesar 0.681, menunjukkan rata-rata $68.1 \%$ informasi yang terdapat pada masing-masing indikator dapat tercermin melalui dimensi ini.

- Nilai composite reliability didapati hasil sebesar 0.907 lebih besar dari 0.7, sehingga ketiga dimensi mempunyai konsistensi untuk menilai kualitas audit. Nilai EVA didapati sebesar 0,766 atau ratarata $76.6 \%$ informasi yang didapat terdapat pada masing-masing 
dimensi dapat tercermin melalui variabel laten kualitas audit.

- Hasil menunjukkan bahwa kesesuaian dengan SPAP merupakan faktor yang lebih penting dalam mencerminkan kualitas audit, disusul kemudian kepatuhan terhadap SOP, dan yang terakhir deteksi salah saji.

\section{Discriminant Validity}

Berdasarkan pengujian ini didapati akar kuadrat average variance extracted masingmasing variabel laten (nilai pada diagonal) masih lebih besar dibanding nilai korelasi dengan variabel laten lainnya. Data ini dapat dijelaskan variabel laten mempunyai hubungan lebih kuat dengan indikatornya sendiri dibanding dengan variabel laten yang lain.

\section{Model Struktural}

Tabel 1

Hasil Model Uji Struktural

\begin{tabular}{|c|c|c|c|c|c|}
\hline Path & Coefficient & t-statisitcs & p-value & $\mathbf{R}^{\mathbf{2}}$ & Analisis Hubungan \\
\hline $\begin{array}{c}\text { IND } \\
\rightarrow \mathrm{KA}\end{array}$ & 0,219 & 4,130 & 0,000 & & Berpengaruh \\
\hline $\begin{array}{c}\text { PA } \rightarrow \\
\mathrm{KA}\end{array}$ & 0,241 & 5,366 & 0,000 & & Berpengaruh \\
\cline { 1 - 3 } $\begin{array}{c}\mathrm{IND} * \\
\mathrm{SP} \rightarrow \\
\mathrm{KA}\end{array}$ & 0,222 & 3,349 & 0,001 & 0,279 & Berpengaruh \\
\cline { 1 - 3 } $\begin{array}{c}\text { PA } \\
\text { SP } \rightarrow \\
\text { KA }\end{array}$ & 0,217 & 6,759 & 0,000 & & Berpengaruh \\
\hline
\end{tabular}

\section{Sumber Tabel: Olahan Peneliti}

Berdasarkan nilai $\mathrm{R}^{2}$ diketahui bahwa independensi, dan pengalaman kerja auditor yang dimoderasi skeptisisme profesional auditor memberikan pengaruh sebesar $27,9 \%$ terhadap kualitas audit.

\section{Pengujian Hipotesis}

a. Pengaruh Variabel Independensi Auditor Terhadap Kualitas Audit

H0: $\rho 1.1=0$ Independensi auditor tidak berpengaruh terhadap kualitas audit

HA: $\rho 1.1 \neq 0$ Independensi auditor berpengaruh terhadap kualitas audit

Hasil pengujian mendapati nilai tstatistic sebesar 4,130 > dari 1,96 dan nilai probabilitas yang didapat mendekati $0<$
0,05, sehingga hipotesis HA dapat diterima. Hal tersebut membuat independensi auditor berpengaruh terhadap kualitas audit.

\section{b. Pengaruh Pengalaman Kerja Auditor Terhadap Kualitas Audit}

H0: $\rho 1.2=0$ Pengalaman kerja auditor tidak berpengaruh terhadap kualitas audit

HA: $\rho 1.2 \neq 0$ Pengalaman kerja auditor berpengaruh terhadap kualitas audit

Hasil pengujian mendapati nilai tstatistic sebesar 5,366 > dari 1,96 dan nilai probabilitas yang didapat mendekati $0<$ 0,05, sehingga hipotesis HA dapat diterima. Hal tersebut membuat pengalaman kerja auditor berpengaruh terhadap kualitas audit.

\section{c. Pengaruh Variabel Skeptisme Profesional Auditor dalam Memperkuat Hubungan Antara Independensi Auditor Terhadap Kualitas Audit}

H0: $\rho 1.3=0$ Skeptisisme profesional auditor tidak berpengaruh dalam memperkuat hubungan antara independensi auditor terhadap kualitas audit

HA: $\rho 1.3 \neq 0$ Skeptisisme profesional auditor berpengaruh dalam memperkuat hubungan antara independensi auditor terhadap kualitas audit

Hasil pengujian mendapati nilai tstatistic sebesar 3,349> dari 1,96 dan nilai probabilitas yang didapat $0,001<0,05$, sehingga hipotesis HA dapat diterima. Hal tersebut membuat skeptisme profesional memperkuat hubungan independensi auditor dengan kualitas audit.

\section{d. Pengaruh Variabel Skeptisme Profesional Auditor dalam Memperkuat Hubungan Antara Pengalaman Kerja Auditor Terhadap Kualitas Audit}

H0: $\rho 1.4=0$ Skeptisisme profesional auditor tidak berpengaruh dalam memperkuat hubungan antara pengalaman kerja auditor terhadap kualitas audit HA: $\rho 1.4 \neq 0$ Skeptisisme profesional auditor berpengaruh dalam memperkuat 
hubungan antara pengalaman kerja auditor terhadap kualitas audit.

Hasil pengujian mendapati nilai tstatistic sebesar 6,759> dari 1,96 dan nilai probabilitas yang didapat mendekati $0<$ 0,05 , sehingga hipotesis HA dapat diterima. Hal tersebut membuat pengalaman kerja auditor yang dimoderasi skeptisme profesional berpengaruh terhadap kualitas audit.

\section{Pembahasan}

\section{a. Pengaruh Variabel Independensi Auditor Terhadap Kualitas Audit}

Variabel independensi auditor (X1) menunjukkan koefisien jalur 0,219 atau $21,9 \%$ dengan tingkat signifikansi sebesar $0,000<0,05$. Dengan demikian dapat dikatakan independensi auditor berpengaruh positif sebesar $21,9 \%$ terhadap kualitas audit. Semakin baik independensi yang diaplikasikan seorang auditor maka akan memberikan kontribusi terhadap perubahan kualitas audit yang semakin tinggi. Hasil penelitian ini sejalan dengan penelitian yang dilakukan Shahibah, et al (2020), Santoso, et al (2020), Wakil, et al (2020), Halim, et al (2014). Semakin tinggi sikap independensi yang dimiliki oleh seorang auditor maka semakin berkualitas laporan audit yang dihasilkan.

\section{b. Pengaruh Pengalaman Kerja Auditor Terhadap Kualitas Audit}

Variabel pengalaman kerja auditor (X2) menunjukkan nilai koefisien jalur 0,241 atau $24,1 \%$ dengan tingkat signifikansi nilai probabilitas sebesar $0,000<0,05$. Dengan demikian dapat dikatakan pengalaman kerja auditor berpengaruh positif sebesar $24,1 \%$ terhadap kualitas audit. Semakin banyak pengalaman kerja auditor maka kualitas audit akan semakin tinggi. Hasil penelitian ini sejalan dengan penelitian yang dilakukan Prasanti, et al (2019), Sarca dan Rasmini (2019), Haeridistia dan Fadjarenie (2019), serta Ningrum dan Budiartha (2017). Pengalaman kerja akan meningkatkan kinerja auditor dalam mengaudit laporan sehingga menghasilkan laporan audit yang berkualitas.

\section{c. Pengaruh Variabel Skeptisme Profesional Auditor dalam Memperkuat Hubungan Antara Independensi Auditor Terhadap Kualitas Audit}

Koefisien jalur hubungan variabel skeptisisme profesional (Y) dengan independensi auditor (X1) dengan kualitas audit ( $\mathrm{Z}$ ) adalah 0,222 atau $22,2 \%$ artinya arah pengaruhnya positif dengan tingkat signifikasi nilai probabilitas $0,001<0,05$. Hasil tersebut menunjukkan bukti empiris bahwa skeptisisme profesional memperkuat hubungan pengaruh independensi auditor terhadap kualitas audit. Hasil penelitian ini sejalan dengan penelitian yang dilakukan Shahibah, et al (2020), penelitian Santoso, et al (2020), dan Zarefar, et al (2016). Hal ini menunjukkan bahwa semakin tinggi sikap skeptisme seorang auditor, maka akan semakin kuat pula sikap independensinya, sehingga dapat meningkatkan kualitas audit.

\section{d. Pengaruh Variabel Skeptisme

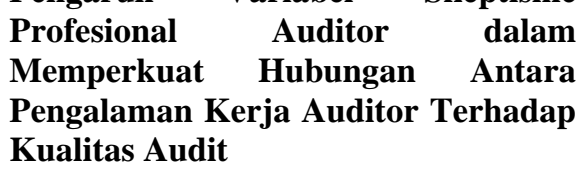
Koefisien jalur hubungan skeptisisme profesional (Y) dengan pengalaman kerja auditor (X2) dengan kualitas audit (Z) adalah 0,217 atau $21,7 \%$ artinya arah pengaruhnya positif dengan tingkat signifikansi nilai probabilitas sebesar 0,001 $<0,05$. Hasil tersebut menunjukkan bahwa skeptisisme profesional memperkuat hubungan pengaruh pengalaman kerja auditor terhadap kualitas audit. Hasil penelitian ini sejalan dengan penelitian yang dilakukan Zarefar, et al (2016). Sikap skeptis auditor akan meningkat seiring dengan lama waktu dan pengalaman kerja auditor dalam mengaudit berbagai jenis industri perusahaan, sehingga diharapkan dapat meningkatkan profesional auditor 
dalam penentuan opini dan meningkatkan kualitas audit.

\section{Simpulan dan Saran}

\section{Simpulan}

Berdasarkan hasil penelitian yang telah dilakukan, maka:

a. Independensi auditor berpengaruh terhadap kualitas audit pada akuntan publik di Indonesia.

b. Pengalaman kerja auditor berpengaruh terhadap kualitas audit pada akuntan publik di Indonesia.

c. Independensi auditor yang dimoderasi skeptisme profesional berpengaruh terhadap kualitas audit.

d. Pengalaman kerja auditor yang dimoderasi skeptisme profesional berpengaruh terhadap kualitas audit.

\section{Saran}

Saran yang peneliti berikan, yakni bagi akuntan publik diharapkan dapat meningkatkan dan melatih sikap skeptisme profesional, dengan selalu melakukan penugasan audit dan menambah jumlah jam terbang audit, sehingga pengalaman audit akan meningkat dan sikap skeptisme profesional pula akan bertumbuh. Bagi akademisi diharapkan dapat memperluas penelitian mengenai kualitas audit ini dengan melihat variabel-variabel lainnya, baik yang berpengaruh langsung maupun tidak langsung. Bagi peneliti selanjutnya dapat memperluas penelitian ini dengan menambahkan variabel lain yang berkaitan dengan kualitas audit, maupun variabel yang memediasi atau memoderasi dalam rangka peningkatan kualitas audit di Indonesia, serta memperluas penelitian tidak hanya pada data kuesioner saja, melainkan pada penelitian yang bersifat kualitatif.

\section{Daftar Pustaka}

Attamimi, F. M., \&Riduan, A. (2015). Faktor-Faktor yang Mempengaruhi
Skeptisme Profesional Auditor. Jurnal Ilmu \& Riset Akuntansi.

Deangelo, L. (1981). Size and audit quality. Journal of Accounting an Economics 3(3), 183-199.

Foster, Bill. (2001). Pembinaan untuk Peningkatan Kinerja Karyawan. Jakarta: PPM.

Gramling, A. A. and Karapanos, V. (2008). Auditor independence: a focus on the SEC independence rules. Issues in Accounting Education 23(2), pp. 247-260.

Haeridistia, Nurlina dan Agustin Fadjarenie. (2019). The Effect Of Independence, Professional Ethics \& Auditor Experience On Audit Quality. International Journal of Scientific and Technology research volume 8 , Issue 02, February 2019. ISSN 22778616

Hai, Phan Thanh, Le Duc Toanc, Nguyen Le Dinh Quy, dan Nguyen Thanh Tung.( 2020). Research Factors Affecting Professional Skepticism and Audit Quality: Evidence in Vietnam. International Journal of Innovation, Creativity and Change. www.ijicc.net. Volume 13, Issue 1, 2020

Halim, Abdul, Sutrisno T., Rosidi, dan M. Achsin. (2014). Effect of Competence and Auditor Independence on Audit Quality with Audit Time Budget and Professional Commitment as a Moderation Variable. International Journal of Business and Management Invention. Volume 3 Issue 6 June. 2014 PP. 6474. ISSN (Online): $2319-8028$, ISSN (Print): $2319-801 X$.

Hurtt, R. Kathy. (2010). Development of a Scale to Measure Professional Skepticism. Auditing: A Journal Practice and Theory. Vol 20 No 1 May 2010. American Accounting Association.

Luthfiana, F. (2018). The Influence of Ethics And Audit Risk On Audit Quality With Professional 
Skepticism As a Moderating Variable: A Case in Public Accounting Firm (KAP) Located in Surabaya. Jurnal Ilmiah Mahasiswa Fakultas Ekonomi dan Bisnis Universitas Brawijaya.

Mautz, R.K. dan Sharaf, H.A. (1961). The Philosophy of Auditing. American Accounting Association.

Nandari, A. W. S., \& Latrini, M. Y. (2015). Pengaruh Sikap Skeptis, Independensi, Penerapan Kode Etik, Dan Akuntabilitas Terhadap Kualitas Audit. E-Jurnal Akuntansi Universitas Udayana.

Ningrum, Made Krisna Kusuma dan Ketut Budiartha. (2017). Etika Auditor Memoderasi Pengaruh Pengalaman Auditor, Kompetensi dan Due Professional Care pada Kualitas Audit. Jurnal Akuntansi Universitas Udayana Vol.20.1. Juli (2017): 61564. ISSN: $2302-8556$

Prasanti, Diyan Hera, Wita Ramadhanti dan Novita Puspasari. (2019). Effect of Independence, Work Experience and Competence on Audit Quality with Professional Ethics as Moderating Variable. Jurnal Akuntansi Aktual Universitas Jenderal Soedirman.

Santoso, Rizky Darmawan, Ikhsan Budi Riharjo dan Kurnia. (2020). Independensi, Integritas, serta Kompetensi Auditor terhadap Kualitas Audit dengan Skeptisisme Profesional sebagai variabel Pemoderasi. Research article published: 31 Juli 2020 doi: 10.21070/jas.v4i2.559.

Sarca, Putu Delsi Nia dan Ni Ketur Rasmini. (2019). Pengaruh Pengalaman Auditor dan
Independensi Pada Kualitas Audit dengan Etika Auditor Sebagai Variabel Moderasi. E-Jurnal Akuntansi Universitas Udayana Vol.26.3 Maret (2019): 2240 -2267. ISSN: 2302-8556

Shahibah, Khansa, Bambang Hariadi dan Zaki Baridwan. (2020). The effect of quality control system on audit quality: Professional skepticism as the moderator variable. International Journal of Research in Business and Social Science 9(4)(2020) 419-425. IJRBS VOL 9 NO 4 ISSN: 2147 4478.

Tawakkal, Ujianti. (2019). Pengaruh Independensi, Integritas, Target Waktu dan Skeptisisme Profesional Auditor Terhadap Kualitas Audit. Jurnal Ilmu Ekonomi. Volume 2 Nomor 2 (2019) April. e-ISSN : 2622-6383

Wakil, Gana Kaflya, Mohd Norfian Afifah, dan Peter Teru. (2020). Auditor Independence and Audit Quality In Nigeria Public Sector: A Critical Review. Journal of Critical Reviews Vol 7, Issue 7, 2020. ISSN-23945125

Wooten, T.G. (2003). It is Impossible to Know The Number of Poor-Quality Audits that simply go undetected and unpublicized. The CPA Journal. Januari. p. 48- 51

Zarefar, Arumega, Andreas dan Atika Zarefar. (2016). The Influence of Ethics, experience and competency toward the quality of auditing with professional scepticism as a moderating variable. Procedia Social and Behavioral Sciences 219 ( 2016 ) $828-83$ 